Published in the Journal of Bahá'í Studies Vol. 2, number 4 (1990)

(C) Association for Bahá'í TM Studies 1990

\title{
The Development of Communication and the Communication of Development
}

\author{
K. Dean Stephens
}

\begin{abstract}
The human species is sustained and nourished by a continuous interchange, a sharing of thoughts, opinions, and feelings known as communication. Various media have evolved as aids to the communication process, from the grunts and gestures of prehistoric societies to the modern world or satellites, video, and computerized data. Although communication has always been the key to the process of human development. the phrase "development communication" only came into vogue in the last twenty years, first using radio and other mass media in one-way, top-down broadcast form to "sell" someone's idea of development to the "ignorant" and downtrodden. As these early models failed to produce spectacular results, the idea of participatory development gained support, with the same downtrodden but suddenly less ignorant public given increasing access to development communication channels. New models are needed to deal with the communication of development: a multidirectional consultative process based on sharing, participation, interchange, and mutual respect and trust. Where is the society that could not benefit from such a process? This paper will briefly synthesize past efforts in development support communication and then suggest new models for development through communication. in a process commencing at the local level.
\end{abstract}

\begin{abstract}
Résumé
Le genre humain est soutenu et nourri par un flot conlinu d'échange; un partage de pensées, d'opinions et de sentiments qu'on appelle la communication. Divers véhicules ont eté développés pour faciliter ce processus de communication, allant des grognements et des gestes des sociétés préhistoriques aux satellites, aux vidéos et aux données informatiques du monde moderne. Bien que la communication ait toujours eté la clé du developpement humain, la notion de «communication pour le développement» n'est devenue populaire qu'au cours des vingt dernières années et on employait, au début, la radio et d'autres moyens de communication de masse pour transmettre, de haut en bas des messages à sens unique visant a «vendre» aux «ignorants» et aux opprimés l'idée du développement élaborée par certains. Puisque as premiers modèles n'ont pas produit de résultats spectaculaires, l'idée d'un developpement participatif a pris de l'ampleur, donnant à ce même public opprimé mais tout à coup moins ignorant un accès plus grand aux canaux de communication pour le développement. De nouveaux modèles sont maintenant nécessaires pour communiquer le développement, tel qu'un processus consultatif et multidirectionnel fonde sur le partage, la participation, l'échange, de même que sur la confiance et le respect mutuels. Quelle société ne bénéficierait pas d'un tel processus? Cet article présente brièvement une synthèse des efforts déployés dans le passé pour aider à communiquer le développement et propose ensuite de nouveaux modèles de développement par la communication, au moyen d'un processus commençant à la base.
\end{abstract}

\section{Resumen}

El género humano es sostenido y nutrido por un medio continuo de intercambio, una repartición de pensamientos, opiniones, y sentimientos conocidos como comunicación. Varios medios han evolucionado como ayudas al proceso de comunicación, desde los gruñidos y gestos de sociedades pre-historicas hasta el mundo moderno de satélites, video, y datos cumputadorizados. Aunque la comunicación siempre ha servido de llave al proceso de desarrollo humano, la expresión "comunicación sobre desarrollo" se ha hecho de moda unicamente en los ultimos veinte arios, usando primero el radio y otros medios masivos en dirección unica, de arriba hacia abajo, con estilos de radiodifusión que intentan "vender" el modelo de desarrollo de algún particular a los dizque ignorantes y oprimidos. Como estos modelos tempraneros no lograron producir resultados espectaculares, ganó apoyo el concepto de desarrollo participatorio con el mismo publico, oprimido pero repentínamente menos ignorante, recibiendo acceso aumentado a los canales de comunicación sobre desarrollo. Se necisitan nuevos patrones para tratar con la comunicación del desarrollo: un proceso consultativo polifacético basado en la repartición, participacón, intercambio, y respeto mutuo y confiabilidad. Adonde se encuentra la sociedad que no beneficiaría de tal proceso? Esta disertacion hara síntesis breve de los esfuerzos del pasado en comunicación sobre apoyo al desarrollo y 
entonces sugerirá nuevos modelos para el desarrollo por medio de la comunicación, en un proceso que comienza al nivel popular.

Although "there are as many paradigms and theories about communication as there are professors of communication" (Ploman, "Communications" 5), it might be useful to consider a few salient definitions of the subject in an attempt to maximize the communication of this treatise. Communication is "a pre-condition for all social organization, whether among animals or humans...without communication there can be no community" (Ploman, "Communications" 7); "a process of democratic social interaction through an exchange of symbols serving human beings to voluntarily exchange experience" (Jakubowicz, "Mass" 1); it involves both "change or exchange" and "rendering common," as well as a more recent emphasis on interactivity (d'Arcy, "Right" 2). It is sharing (Rogers, Everett, and Kincaid, "Communication" 16) - a "desire to share ourselves with others" (Stuart, "Village" 5).

Communication is a universal quality of humanity, an omnipresent component of our existence; "our capacity to communicate is largely decisive in determining whether we can be called a social being andtherefore-human" (Eurich, "New Awareness" 34; $c f$. Freire "Pedagogy"). "Only communication can create social behaviour from individual behaviour: behaviour which creates togetherness, community" (Eurich, "New Awareness" 34). All life depends on communication. Its waves and patterns (Cassirer, "Communications" 6) exist in the nuclear activity of each atom, the chemical reactions in every cell, in the transmission of life itself from generation to generation (Fisher, Right). Association is an organic process, with humans interrelating as naturally as atoms, stellar masses, and cells; while physical interactions occur de facto, human participation and sharing demand communication as prerequisite (Dewey, Public).

Whereas all animals recognize and use signals for communication, only human beings can communicate through symbols (Cassirer, Essay 32-33). Any history of human communication is inseparable from a study of the use of symbols (Duncan, Symbols). "Man's freedom is freedom to communicate through symbols of his own creation. This is his glory and his burden. Naming can be either a blessing or a curse" (Duncan, Symbols 247).

Since the blessings provided by the freedom of symbolic human communication might be more obvious than potential curses, a brief list of constraints is in order. One immediate problem on this planet is the multiplicity of languages and cultures, so that one person's symbol may have slightly or totally different interpretation for another, or no meaning whatever:

That is not what I meant at all;

That is not it, "at all. (Eliot, "Love Song")

"One of the cherished ideas of our times and of earlier times is that contact between societies leads to understanding. The durability of this notion is awesome considering the thousands of years of documented evidence to the contrary" (Hanvey, "Cross-cultural" 46). Even if understood, mere information does not constitute communication (Fuglesang. About Understanding). Information is potential communication, when used in the right way in proper social context. "Communication between people thrives not on the ability to talk fast, as some mass-media prophets seem to think, but on the ability to listen well.... it is so simple, and yet we fail continuously in our attempt to communicate because of an egocentric attitude" (Fuglesang, About Understanding 28). "Human communication," according to Tehranian, "is predicated upon the existence of an epistemic community based on shared experiences and common structures of meaning" ("Modernization" 43).

Communication also represents empowerment: whoever is most able to communicate, whoever dominates communication channels, can dominate and thereby dehumanize others (Freire, Pedagogy ch. 3). "To impede communication is to reduce men to the status of 'things' - and this is a job for oppressors, not for revolutionaries" (Freire, Pedagogy 123). Mass communication media can sell a concept (Beyond 10), manipulate an audience, or brainwash the public (Kogawa, "New Trends" 148), sometimes in the guise of "communication for development" (Jamison and McAnany, Radio 18). Elites tend to take the most active interest in governmental affairs and may therefore become de facto controllers of the media (Davison, "Role" 32).

But communication "is indispensable to all: to the individual, to the community, to society (Fisher, Right): "without it, there can be no cooperation, no peace. Community depends on communications. The history of civilization is the history of communication. The invention of speech, of writing, of printing, of the telegraph, radio and television, up to the so-called communication explosion of the present day are all milestones in the story of human life, marking new stages in its development, new opportunities for choice" (Fisher, Right 9).

Communication is a precondition for social organization (Ploman, "Communications" 5), and media have always been used by our species. "In this sense, all human societies have been information societies...however, 
communications and information were largely taken for granted,...placed in the service of other social activities" until recent years when "communications and information per se have become issues in society" (Ploman, "Communications" 7). For untold millions of years, speech evolved from simple sounds and gestures to a complex, symbolic medium. Prehistoric societies learned to communicate through paintings, crafts, and ornamentation. Then came writing, enabling cultures to leave written histories; followed quite recently by print, exponentially expanding access to knowledge; and even more recently joined by electronic media: public address, radio, television, and computers (Duncan, Symbols; McLuhan, Understanding; Real, Mass-Mediated).

The media are "magic multipliers" (Nkinyangi, "Review"), amplifiers of messages good and bad. They can be used by an elite to persuade and manipulate by paternalistically conveying their values, habits, and tastes; to transmit orders along with the ideas and attitudes leading to their acceptance in authoritarian systems (Jakubowicz, "Mass"); or in commercial fashion to sell not only the products and culture of the corporate giants but also the very idea that hedonism is "in" (Bell, Cultural 70-80; Delozier and Shimp, Promotion 67). More positively, media can be employed to share information, to educate; and to lead to the development of peoples (Bell, Matching; Lasswell, Communication).

\section{Development Support Communication}

The term development lends itself to at least as many definitions as does the term communication. Early ideas tended to see development as modernization or industrialization (see Arbab, "Development"), where an elite group or country would extend a helping hand-usually in the form of economic or technical assistance-to some "underdeveloped" region (Eyford, Bahá'í Studies Notebook 1-2). Over a period of thirty years or more, many diverse strategies were employed-many top-down, paternalistic exercises doomed to achieve little or nothing of true human development. These included large infusions of capital, new technologies, coercion, manipulation, incentives, disincentives, propaganda, and education (Eyford, Bahá'í Studies Notebook 1-2).

As the field of development burgeoned, a new discipline called "development support communication" was born, largely to combine the techniques of advertising, publicity, and marketing with those of communications and mass media use (Nascimento, World Communication Environment 15-27). Development support communication can employ one or more distinct strategies, including media-based projects centered around someone's favorite medium; instructional design strategies focusing individual learning and employing planning, implementation, and evaluation stages; participation strategies, where community cooperation and personal growth are central principles; and marketing techniques, "probably the most hard-headed, and sometimes the most banal, of the communications strategies. 'If you can sell toothpaste, cigarettes and beer, why can't you sell health, agriculture, and family planning?"' (Beyond the Flipchart 6-10).

Descriptions of development support communication projects abound (Beyond the Flipchart; Accion Cultural Popular; Jamison, Radio for Education; McAnany, Radio's Role; de Noriega, Broadcasting in Mexico). Ongoing examples include RADECO in the Dominican Republic (Eshgh, Radio Assisted Education), LRCN in Liberia (Burke, Case Study in Communications Planning; Kweekeh, Radio of Rural Development), Radio Learning Groups in various countries (Crowley, Radio Learning Group), and RLAP in Kenya (Imhoof, Interactive Radio in the Classroom)(see below). For present purposes, a few quotations from earlier cases will suffice:

All present-day governments recognize the power of communications. Most of them spend considerable sums on radio and television and go to considerable trouble to publicize political and economic developments. A good deal of this official information work is devoted to image-building-persuading citizens in various walks of life that the government has their interests at heart and is doing a good job. (Balcomb, Communications for Development 3)

The Department of Information and Propaganda's conference in 1975 decided that radio and people's newspapers should be given priority as means of communications in the villages.... however, it was seen that peasants would not be able to buy radios in the short term.... in addition, it was found to be impossible to maintain people's newspapers in all the villages because of, among other things, a lack of continuity and or guidance for people in charge of them. (Mozambique, Ministry of Information, Communication of Development 3)

In a small, poor, developing nation, struggling to escape thc history of colonialism's social and material servitude, the purpose of the media is to educate, to persuade productive attitudes, to raise the national conscience and then, perhaps, to entertain. (Nascimento; World Communication Environment 49) 
Tanzanian officials and other personnel at all levels get much of their news and information from circulars issued by senior ministry officials at Dar es Salaam and at various regional headquarters.... official letters stressing the consistency of Mtu ni Afya with national objectives, pointing out its integration with previous mass campaigns and adult-education work, and urging staff at all levels to support the campaign were sent out by the principal secretaries, by senior civil servants of the Prime Minister's Office and of the education and health ministries, and by the head of TANU's political education department. (Hall, Tanzania's Health Campaign 28)

Radio should play a key role in making information for rural development more widely available, provided national elites give the same careful attention to problems of internal as well as external dependency. (McAnany, Radio's Role 25)

When I went to India in 1967 as UNICEF's regional public information officer it was presumed that I knew something about the arts of mass persuasion. I soon found myself called upon to advise on the communications aspects of development projects. Given my background as a writer of newspaper articles and a fabricator of publicity handouts, I naturally thought in terms of target audiences, delivery systems, multi-media campaigns and such. (The warlike nature of these terms, which are common to most communications handbooks, did not occur to me at the time.... The communicator is usually conceived as a kind of artillery man who bombards his targets with messages with enough "feedback" built into the system to enable him to correct his fire.) (Bell, Matching of Scales 4)

Pakistan Broadcasting Corp. definition of development: "a process to make maximum use of human and available natural resources to increase the productivity of goods and services for the welfare of the society." (Abbas, Ruroawareness through the Audio Channel 267)

Everyone wants to be on the air when the greatest audience is available, but it would make little sense for us $[\mathrm{CBC}]$ to be churning out relevant northern programs if they were replaced locally. (Ward, Access Radio in the Northwest Territories 2)

In many countries where audience involvement was minimal, development support communication failed to bring the benefits of development to the majority of the population (Campbell, InterMedia). Most of these projects involved one-way interventions (Nkinyangi, Methods and Media in Community Participation) with evaluation by quantitative tabulation, which all too often ignored the fact that the rich got richer and the poor got poorer (Freire, Pedagogy of the Oppressed).

\section{New Paradigms: Development}

"Development means the development of people not things." This statement of Tanzanian President Julius K. Nyerere quoted in Hall (Tanzania's Health Campaign 127) is a good summary of changing development concepts in the past two decades. The idea of "development as if people mattered" sprang, as much as anything, from the failures of development projects imposed from above or from afar: "Whose privilege is it to define the learning needs of the deprived and the poor? The educationalists have for too long betrayed the people with their professionalism" (Fuglesang, "Beans in a Bowl" 8). Robert Chambers' brilliant essay Rural Development: Putting the Last First offers a new paradigm of assistance, a modus operandi easier to capture in prose than to put into practice. In the preface, Chambers reports an interview in Bangladesh: "Gentlemen, whatever are you writing so much about the poor people? God, himself, does not love the poor people: so what help will your writing do?' That is a discomforting question which I cannot answer. So let me now pass it on now to the reader" (2).

"The extremes of rural poverty in the Third World are an outrage.... not just that avoidable depravation, suffering and death are intolerable; it is also that these coexist with affluence" (2). Directed primarily at the "development professional," Chambers' uncompromising thesis is that they (we) get into the village and get on with the work of saving untold millions from utter despair, of facilitating the self-development of people everywhere: "We, these outsiders, have much in common. We are relatively well-off, literate, and mostly urban-based. Our children go to good schools. We carry no parasites, expect long life and eat more than we need.... The puzzle is that we, the people of this class, do not do more" (3). Professionals, caught in an "urban trap" of niceties, social obligations, and city responsibilities, resort to "rural development tourism": a quick jaunt to a nearby "model" community for a carefully guided tour where equipment glistens and local people offer their thanks, often out of fear of losing whatever gains have been made (7-12). 
The biases in such a widely practiced system are obvious: the still poor and unconvinced are hidden, sites are toured during their best season, isolated communities are seldom visited, and people are reluctant to tell all to a stranger-aloof government official or esoteric academician-who may have the power to cut off aid. Moreover, both the "negative academics" in their ivory towers and the result-oriented "positive practitioners" in the field must learn to listen - to each other and to the rural poor - to learn truly to "put the last first"(Chambers, 56, 106).

Others believe that development must originate with the underprivileged, that a "pedagogy of the oppressed" is necessary to give the poor the communicative skills to define and struggle, for their own freedom (Freire, 49); that resources which exist at the local level must be identified and used (Hewett, 73); that "progress in the development field will largely depend on natural stirrings at the grassroots, and it should receive its driving force from those sources rather than from an imposition of plans and programs from the top" (Universal House of Justice, letter October 20, 1983).

Development must include social considerations and "the whole dimension of cultural and spiritual self-realisation embracing creativity, quality of life, and the rights of man," according to da Costa (Applying a New Concept of Development 24); development is original, not the imitation of some model; it must be self-determined and selfgenerated but cooperative in an international sense; it must respect the integrity of both natural and cultural environments, and the social structures necessary to maintain social cohesion; and thus protected against the imposition of alien values, it must be accepted and assisted by national authorities: a free play of economic forces will not "automatically lead to an equitable diffusion of scientific and technological potential...science and technology need to play a direct and active" role in development (da Costa, Applying a New Concept of Development 24).

"In particular, development needs to be directed towards a just and equitable social order which requires...structural transformations allowing for the participation by all sectors of the population in the benefits of science and technology, and not just the negative effects." It must "respond to the choices made by the population as a whole. The idea that technological decisions must be imposed on people should be categorically rejected." Development must be all-inclusive and innovative, based on a realistic definition of national needs (da Costa, Applying a New Concept of Development 155).

It has become increasingly clear that development is not simply a matter of economics but, rather, touches all aspects of society and draws from all its dynamics (Eyford, Bahá'i Studies Notebook 1-2). "At the very root of the question is our eternal quest for a more complete understanding of the nature of man and the manner of his development. What 'theory' and 'practice'...conforms best with the reality of man? How can full human potential be realigned and released?...How can man serve society; how can society serve the best interests of man?...Our greatest underutilized, inexhaustible renewable resource is the human spirit" (1-2).

In the Bahá'í view, the unity of humankind will be attained through "the achievement of a dynamic coherence between the spiritual and practical requirements of life on earth" pivotal to "the development of the social and economic life of peoples" and the "reconstruction of society" (Universal House of Justice, letter October 20, 1983).

\title{
New Paradigms: Development Communication
}

\author{
Who but a lunatic \\ Will bandy words with boxes \\ With government rediffusion sets \\ Which talk and talk and never \\ Take a lone word in reply(?)
}

This poem by Nigerian playwright Wole Soyinka (cited by Pine, Broadcasting: Public or Private 18) illustrates the changing dynamic of development communication from vertical, imposed modes to something more horizontal and participatory. The history of this trend has been widely documented (Beyond the Flipchart; Diaz, Communication and Rural Development; Gottleib, Village Radio; Ploman, Communications Revolution; Splichal, Radio as a Means of Communication).

Tehranian (InterMedia 19) identifies three separate processes involving development and communications: the development of communications facilities and infrastructure corresponding to the process of accumulation in development generally; development by communications focusing more on software than hardware, corresponding to the processes of socioeconomic, political, and cultural mobilization; and development through communication wherein satisfaction is given to the expression of separate interests, identities, and ideological persuasions of various sectors of society. 
Howkins calls the broadcast spectrum a "basic resource," and argues for increasing global, public participation in its management ("The Management of the Spectrum"). Ploman sees the need for a policy which is at once global and centrally planned, yet increasingly individualized ("Proposal: A Media Policy"). According to Jakubowicz, communication must be decentralized and democratized ("Mass and Communication"), with all components of the process-sender, message, and receiver-open to anyone at any time ("Democratizing Communication in Eastern Europe").

Adhikarya and Colle argue that "rural development is not something that planners 'do' to rural people through communication....By itself, communication does not produce development. Development is something rural people themselves do, or it does not happen" (Adhikarya and Colle, Reaching Out I). According to Fuglesang, "public information, formal and nonformal education, and other activities in the field of social communication should ultimately and ideally occupy themselves with solutions to the problem of redistributing the information resources of society - a process that should lead to a larger degree of equality in the total social communication system" (Fuglesang, "Beans in a Bowl" 9).

Beltran sees the poor as "universal underdogs," kept in near slavery by systems supportive of an urban minority in most "developing" countries. He sees that land reform is a myth in consequence; that technology assists the "haves" at the expense of the "have-nots"; that some new panacea is always ready to rescue the situation. "It is within such an archaic and unfair pattern of social relationships that 'communication for rural development' has to be appraised. For communication is neither independent of the determinant societal structure nor can it be deemed a magician capable of changing that structure by itself alone" (Beltran, Rural Communities in Developing Countries 4 I).

"We must set limits to the growth of technological communication, and be prepared for alternatives," according to Eurich, "before irreparable damage is done. We must acquire the habit of thinking about communication in ecological terms." Communication cannot work in isolation. It incorporates togetherness, the exchange of feelings, love, affection in all its forms, justice, and social freedom. Much of the mass communication media of today are serving to isolate, actually "communicating" less and less (Eurich, 34-37; cf. Casals-Andrews \& Eshgh, "Radio Education").

One of the most important tools of development communication is radio, a powerful force potentially available universally, and of great appeal when used as a participatory medium in oral cultures (Allen and Anzalone, Learning by Radio; Diaz Communication and Rural Development; Stephens, Alternate Energy for Radio Stations ). Allen and Anzalone make a good case for learning by radio, in a scenario that does not necessarily include literacy (Allen and Anzalone, Basic Education by Radio is an Alternative 154). "Radio Stations don't seem to have anything to say anymore," says Stuckens. "That is why it is necessary to invent radio. Every day" (Stuckens, Radio Radio What is Radio? 14). "Therefore one must get live news and ask people involved with social movements to come and sit down in front of the microphone, and be active participants.... What this is about is not 'Mass Media', but really local, interconnected, information exchange units."

Such "come in and talk" or "free forum" radio can be found all over the world, from models licensed and supported by government funds to illegal pirate operations transmitting from clandestine locations. ${ }^{1}$ A good example is mini-FM station Setagaya MaMa, a one-kilometer radius micropower station located in a small natural food bar in Tokyo. The bar keeps an open microphone on air whether or not anyone is consciously talking over it: "One time, when several people began talking about community politics, some listeners rushed to the station and joined in the discussion" (Kogawa, Free Radio in Japan 3).

A number of other current participatory radio models are worth noting. Interactive radio demands constant action and response from primary school children learning standard curriculum subjects adapted to that format in Nicaragua, the Dominican Republic, Thailand, Kenya, and Liberia. Science is being added to language arts, mathematics, and general studies. Other programs are designed for adult radio learners.

Some communication models may not require a broadcast license in all countries. Wired speaker delivery systems, with or without community access, exist in China, Peru, and Mozambique. Carrier current radio transmission is common on college campuses in the United States. "Leaky cable" radio broadcasts to listeners driving down a highway or in houses up to 150 feet away from a buried or suspended cable. Micropower AM is legal in the United States under certain conditions as is mini-FM in Japan. Two-way radio is used for health care, social services, and general communication variously in Guyana, East Africa, Canada, Alaska, and Central America. Audiocassettes and videocassette recorders have also been used successfully to promote interactive, participatory communication, both through "instant replay" techniques to help people become more articulate and through taping interviews for later replay for policymakers or over the air.

Native radio stations serve the needs of indigenous communities in Canada, the United States, Bolivia, Ecuador, and Peru. Most of these stations are owned and operated by the group indigenous to the region, 
emphasizing native culture, music, language, stories, and traditions. As an oral medium, radio is particularly suited for this task. An important function of many stations is that of clearinghouse for relaying personal messages in areas where transportation and access are poor. The messages range from such life-and-death matters as health emergencies to simple greetings from one person or community to another.

Bahá'í radio stations on three continents combine participatory, indigenous radio with cultural, educational, and spiritual fare in formats that have met with great success. In a study of the audience of Radio Bahá'í, Ecuador, Hein found the station to be by far the most popular in the area due to broadcasts in the local language, the choice of local villagers as staff members, and the priority placed on content over technology. The stations constitute organic, ongoing experiments in development communication, part of a larger dynamic of development taking place in Bahá'í communities the world over.

\section{Village Radio}

"While others try to reach the moon, developing countries must try to reach the village" (Nkinyangi, Methods and Media in Community Participation 22). This quotation by President Nyerere of Tanzania captures the paradigm of development in much of the world today: to "reach" the village, not with top-heavy "development" messages but rather with access to the process of development, including knowledge and communication.

This type of development effort will require a vast increase in locally produced, relevant information, and will need decentralized programming with the full participation of those whose interests it purports to serve .... Special attention will have to be given to the location of communications equipment in the villages and the poorer urban sectors in order to ensure free and equal access to, and use of, the equipment. (Soedjatmoko, Future 12)

Contreras et al. call for "startling innovations" to "inject localness into the communication process and to scale down the media from mass systems to people-sized and small-community-sized media"(Contreras Cross-Cultural Broadcasting 41).

"There is no reason why every village in the Third World should not have a radio station of its own" (Crookes "Down to Basics" 5). Village radio demystifies, decentralizes, and "deprofessionalizes" communication (Jajubowicz, "Mass and Communication"; Ploman, "The Communication Revolution"), becoming the facilitator of an "alternative philosophy of development as a process in which people themselves are the key actors"; where "revolutionary use of the media for social change should not require manipulators to disappear but on the contrary must make everyone a manipulator"(Nkinyangi, Methods and Media in Community Participation 11). "Community media are adaptations of media for use by the community, for whatever purpose the community decides....They are media in which the community participates as planners, producers, and performers. They are the means of expression of the community, rather than for the community"(Berrigan, Community Communications 8).

A village radio station can vary in cost from less than ten dollars to more than ten thousand (Stephens, "Power to the People"). Transmissions can be made on the AM or FM bands, from equipment ranging between micropower wireless microphones to full-fledged open broadcast systems. Transmissions may radiate from short lengths of wire, from "leaky cables" strung or buried throughout the community, from "professional" AM towers and FM antennas, from electrical wiring, or be contained in a cable passing from house to house. (Stephens, "Micropower and 'Leaky Cable' Village Radio"). Village stations may use solar or other alternative energy where there is no access to electrical mains, even providing cabled power for radio receivers in each dwelling. Village radio is now using simple, low-cost technology to "put the last first" (Chambers, Rural Development), to provide the poor and forgotten people of the earth with a key to their own development.

\section{The Communication of Development}

Traditional "development communication" models are, for the most part, those employing the communications media in a manipulative sense: to "sell" a product, project, or service to some "target" audience, often the local populace of a materially "underdeveloped" nation or area (Balcomb, "Communication for Development"). In the best of cases, this communication for (in support of) development becomes a vehicle for the education of the masses, letting them know the benefits of some health campaign, agricultural project, or whatever. Even then, communication is largely a vertical process, with top-down messages given in presentable form to the people to be thus "served."

At worst, communication for development is high-pressure advertising, pure and simple, made to convince the members of a "target" audience that they really cannot go on living without a particular shiny new machine, packaged foodstuff, patent medicine, or some bureaucracy's latest organizational panacea (Beyond the Flipchart 10; 
DeLozier and Shimp, Promotion Management). Such top-down messages can create or sustain dependence, feelings of inadequacy, or reliance on things foreign to the culture (Lee, Guidelines for Peace Corps). In reality, such outcomes are the antithesis of true development (Campbell, "Development Communication"; Eurich, "Media Ecology");

Maybe the time has come to give new meaning to development communication, i.e., the communication of development, starting with the accepted terms of "communication" and "development" themselves. Webster's Unabridged Dictionary defines "communicate" as "to share; to participate," and lists the second definition of "communication" as "intercourse by words, letters or messages; interchange of thoughts or opinions, by conference or other means." All three definitions of "develop" are of interest (1) "to come into being or activity"; (2) "to become larger, fuller, better, etc.; grow; evolve"; (3) "To become known or apparent; to be disclosed."

Uniting these concepts, the communication of development takes on a quite new meaning: to share, to participate, to interchange thoughts and opinions focused on developing; to bring a community or a people into being or activity; to grow, evolve, become known.

What is suggested is a dynamic process involving grassroots participation where communication becomes the vehicle for enlightened consultation-the interchange of thoughts and opinions-about "developing or being developed." Where is a population that doesn't need developing, less in some strictly material sense than for the "growth," "advancement," "evolution," and "fullness," words that suggest underlying spiritual and human values?

The communication of development can apply equally well in the inner city of Detroit or New York's Wall Street; a terminal ward or rehabilitation centre; a kindergarten classroom or old-age home; a village in Uganda or a city block in Tokyo. Shared communication is the basis for all human interaction. But all too often, modern mass "communications" media have actually become barriers to the process of communication, isolating individuals in front of a television set or inside a pair of headphones (Eshgh, Radio-Assisted Community Basic Education; Kogawa, "New Trends in Japanese Popular Culture"). The communication of development must become the voice of consultation, bringing people together to interchange, share, and participate; to consult on the means for development; and then to develop.

Shoghi Effendi called frank and unfettered consultation the "bedrock" of an unique order for our times (Bahá'í Consultation 10); "For where a united will exists, nothing can effectively oppose and hamper the forces of constructive development" (Principles of Bahá'í Administration 49). "The heaven of divine wisdom is illumined with the two luminaries of consultation and compassion..." according to Bahá'u'lláh (Tablets 26). A consultative body should be established in every community: "It is incumbent upon them to take counsel together and to have regard for the interest" of all for the sake of God, "even as they regard their own interests..." (Bahá'u'lláh, Kitáb-iAqdas 13).

Among the "prime requisites" for consultation are pure motive, a radiant spirit, detachment, attraction to God, "humility and lowliness amongst His loved ones," and patience and long-suffering in the face of difficulty (Shoghi Effendi, Principles 21). With reference to detachment, those consulting "must learn to express their views frankly, calmly, without passion or rancour. They must also learn to listen to the opinions of their fellow members without taking offence or belittling the views of another" (Universal House of Justice, Lights of Guidance 179). Such a process requires love, kindliness, moral courage, and humility.

The concentric circles of figure 1 attempt to capture this development paradigm, as well as several roles of communication in the process: A local village or community consults on development needs and desires [1], then checks local human and material resources [2] to see if the need can be responded to locally. Further consultation ensues [3], generating messages "we have" [4] and/or "we still need" [5]. The latter is passed to the next level, the municipality in the exhibit, for communication and consultation leading to a second level resource check [6], further consultation [7], and a response message [8]. The flow is not unidirectional: each level from local to international has cultural, human, and/or material resources to offer the rest. This process can continue to the state or province, the nation, and the world, with consultation and resource checks at al levels-communication paths rather distinct from top-down development models so prevalent today. 


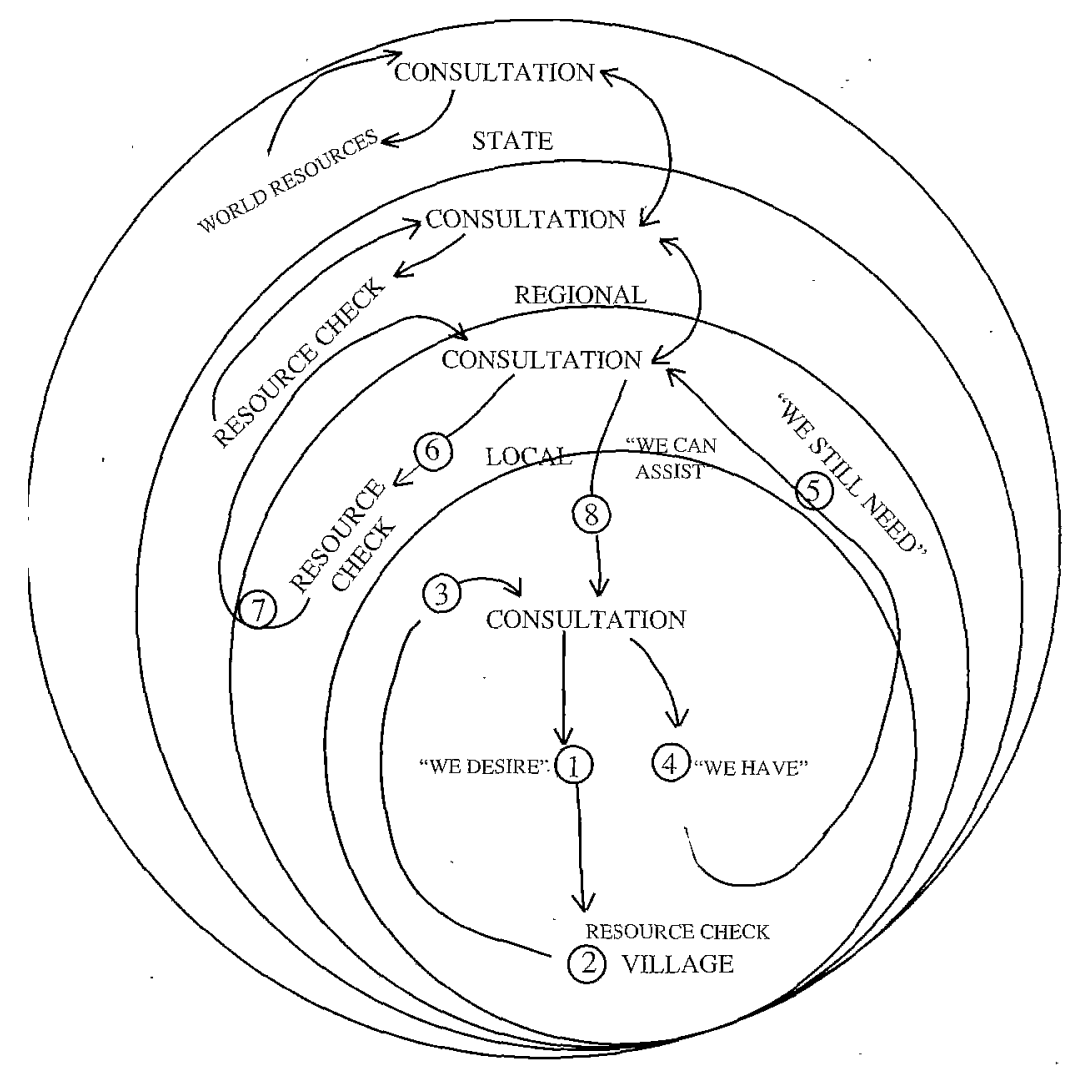

The principles of constructive consultation come into play at every stage of true development communication from interpersonal to international:

The courage, the resolution, the pure motive, the selfless love of one people for another-all the spiritual and moral qualities required for effecting this momentous step towards peace are focused on the will to act. And it is toward arousing the necessary volition that earnest consideration must be given to the reality of man, namely, his thought. To understand the relevance of this potent reality is also to appreciate the social necessity of actualizing its unique value through candid, dispassionate and cordial consultation, and of acting upon the results of this process.... The very attempt to achieve peace through the consultative action ...can release such a salutary spirit among the peoples of the earth that no power could resist the final, triumphal outcome. (Universal House of Justice, "To the Peoples" 19) .

Frank and unfettered consultation represents communication at its finest-truly a major step toward the achievement of mutual trust, understanding, and the development of all humanity. Communication media, to the extent that they become the facilitators of such Open dialogue, can serve to hasten the day when the earth becomes "one country, and mankind its citizens" (Bahá'u'lláh, Tablets 167). 


\section{Notes}

1. Duckworth, "Tokyo: Small Scale in a Big City." Interadio; Guattari, "Las Radios Libres Populares, " De las Ondas Rojas a las Radios Libres; Hochheimer, "Community Radio in the United States: Whom does it Serve?"; Intermedia Staff, "The Chinese Way of Broadcasting"; Kogawa, "Japanese Block-Wide Radiocasts" World Paper; Maeda, "Community Radio Survey-U.S.A."; Milam, The Radio Papers; Mitchell, A Resource of the Active Community; Radio Farabundo Mati Staff, "Radio in the Trenches," Interadio; Rodrigo and Ruiz-Collantes, "Cronologia," De las Ondas Rojas a las Radios Libres; Sofia, "Community Radio Survey: Italy and Europe."

\section{Works Cited}

Abbas, Qaisar. "Ruroawareness through the Audio Channel: A Communication Strategy for Rural Broadcasting in Pakistan," RTV. Belgrade, Yugoslavia, 1983/3.

“Accion Cultural Popular: Report of a Field Evaluation.” Development Communication Report (DCR) 29 (Jan. 1980).

Adhikarya, Ronny, and Royal D. Colle. Reaching Out: The Role of Audio Cassette Communication in Rural Development. Singapore: Asian Mass Communication Research and Information Centre, 1983.

Allen, Dwight W., and Stephen Anzalone. "Learning by Radio: The First Step to Literacy." Prospects 3.2 (1978). . "Is Literacy the Only Road to Learning? Basic Education by Radio as an Alternative." DCR 44 (Dec. 1983).

Amarelo, Odete. "Literacy through Radio." Vanguardia. Arecibo, Puerto Rico: The Vanguard Trust, 1.4 (Oct. 1988).

Amt, William. “Audiotheques Rurales in Mali.” DCR 58,3(1987).

Arbab, Farzam. "Development: A Challenge to Bahá'í Scholars,” Bahá'í Studies Notebook 3.3/4 (Feb. 1984).

d'Arcy, Jean. "The 'Right to Communicate' and the Meaning of Words.” InterMedia 11.2 (Mar. 1983).

Bahá'í Consultation. Comp, Research Department Bahá'í World Centre. London: Bahá'í Publishing Trust, 1978.

Bahá'u'lláh. Synopsis and Codification of the Laws and Ordinances of the Kitáb-i-Aqdas. Haifa: Bahá'í World Centre, 1973.

. Tablets of Bahá'u'lláh Revealed after the Kitáb-i-Aqdas. Haifa: Bahá'í World Centre, 1978.

Balcomb, John. "Communication for Development: From Propaganda to Dialogue and Entertainment." UNICEF News 84.2(1975).

Bell, Daniel. The Matching Scales. London: International Institute of Communications, 1979.

_ . The Cultural Contradictions of Capitalism. New York: Basic Books, 1976.

Beltran, Luis Ramiro. "Rural Communities in Developing Countries: The Prospect of Communications." Issues in Communication. London: International Institute of Communications. No. 2,1978.

Berrigan, Frances I. Community Communications: The Role of Community Media in Development. Paris: UNESCO Press, 1979

Beyond the Flipchart: Three Decades of Development Communication Washington, D.C.: Academy for Educational Development, 1985 
Block, Clifford H. "Interactive Radio and Educational Development.” DCR 49 (Spring 1985).

Burke, Richard C. "A Case Study in Communication Planning: The Liberian Rural Communication Network.” DCR 31 (July 1980).

Campbell, Frank. “The Practical Reality of 'Development Communication'.” InterMedia 12.2 (Mar. 1984).

Casals-Andrews, Beatriz, and Ruth Eshgh. "Radio Education in the Dominican Republic.” DCR 55 (Autumn 1986).

Cassirer, Ernst. An Essay on Man. 2d ed. New Haven: Yale University Press, 1973.

Cassirer, Henry R. “Communications-Communication.” InterMedia 12.6 (Nov 1984).

Chambers, Robert. Rural Development: Putting the Last First. London: Longman Group, 1983.

Christensen, Philip R. "The Radio Language Arts Project: Adapting the Radio Mathematics Model." DCR 49 (Spring 1985).

Contreras, Eduardo, et al. Cross-Cultural Broadcasting. Paris: UNESCO Press, 1976.

Correa, Xavier. "People's Participation in Popular Radio: Peru and Bolivia." Ideas and Actions (FAO) 159 (1984/6).

da Costa, Joao F. “Applying a New Concept of Development.” InterMedia 7.5 (Sept. 1979).

Crewe, David R. Personal Correspondence on Dorset and Baker Lake, NWT mini-FM radio stations, Dec 1986.

Crompton, Richard H., and William B. Jackson. "Highway Information Radio Systems-What They Do, How They Work." Proceedings: 41st Annual Broadcast Engineering Conference. Washington, D.C.: National Association of Broadcasters, 1987.

Crookes, Philip. "Down to Basics.” Development Forum. April 1983.

Crowley, David, Alan Etherington, and Ross Kidd. Radio Learning Group Manual. Bonn: Friedrich-Ebert-Stiftung, 1985.

Cutler, Morris. "Using Radio to Teach Language Arts: Pilot Project in Kenya Addressing Primary Needs." DCR 37(Mar. 1982).

Davison, W. Phillips. "The Role of Communication in Democracies," in International and Intercultural Communication. Ed. Heinz-Dietrich Fischer and John C. Merrill. New York: Hastings House, 1976.

De Lozier, M. Wayne, and Terence A. Shimp. Promotion Management and Marketing Communications. Chicago: The Dryden Press, 1986.

Dewey, John. The Public and Its Problems. Chicago: Swallow Press, 1954. Diaz Bordenave, Juan E. Communication and Rural Development. Paris: UNESCO Press, 1977.

Duckworth, Janet. "Tokyo: Small Scale in the Big City.” Interadio 1.1(Spring 1988).

Duncan, Hugh D. Symbols in Society. New York: Oxford University Press, 1968.

Duran, Jane. "Participatory Radio in Arequipa.” DCR 52(Winter 1986).

Eliot, T.S. "The Love Song of J. Alfred Prufrock," in A Treasury of Great Poems. Ed. Louis Untermeyer. 2d ed. New York: Simon and Shuster, 1964. 
Eshgh, Ruth, et al. Radio-Assisted Community Basic Education (RADECO). Pittsburgh: Duquesne University Press, 1988.

Eurich, Claus. "The New Awareness of Media Ecology.” InterMedia 12.2 (Mar. 1984).

Eyford, Glen. Introduction. Bahá'í Studies Notebook 3.3/4 (Feb. 1984).

Fisher, Desmond. The Right to Communicate: A Status Report. Paris: UNESCO Press, 1981.

de Fossard, Esta. “The School Classroom and the Radio Classroom.” DCR 45 (Mar. 1984).

Freire, Paulo. Pedagogy of the Oppressed. New York: Seabury Press, 1974.

Friend, Jamesine, Klaus Galda, and Barbara Searle. "From Nicaragua to Thailand: Adapting Interactive Radio Instruction.” DCR 52 (Winter 1986).

Friend, Jamesine. “A Model for Interactive Radio Lessons: The Radio Mathematics Project.” DCR 49 (Spring 1985).

"Using Feedback for Program Production: Formative Evaluation of Instructional Radio." DCR 29 (Jan. 1980).

Fryer, Michelle, Stanley Burns, and Heather Hudson. "Two-Way Radio for Rural Health Care Delivery.” DCR 51 (Autumn 1985).

Fuglesang, Andreas. "Beans in a Bowl: Observations on Communication and Adult Learning in Developing Countries." DCR 27 and 28 (July and Oct. 1979).

__ . About Understanding. Uppsala, Sweden: Dag Hammarskjold Foundation, 1982.

Galda, Klaus. "The Radio Mathematics Project: New Examples of Technology Transfer.” DCR 45 (Mar. 1984).

Gerber, Michael S. “A Successful Medical Radio Network in East Africa.” DCR 32 (Oct. 1980).

Goldschmidt, Douglas, Heather E. Hudson, and Wilma Lynn. "Two-Way Radio Helps Deliver Primary Health Care." DCR 32 (Oct. 1980).

Gottlieb, Randie. "Village Radio: A Proposal." Unpublished report to Focus Communications, Arecibo, Puerto Rico; 1985.

Green, Lyndsay, and David Simailak. "Satellite Communications Reinforcing Cultural Identity in Canada's Northernmost Reaches." DCR 36 (Dec. 1981).

Guattari, Felix. "Las Radios Libres Populares.” De las Ondas Rojas alas Radios Libres. Ed. Lluis Bassets. Barcelona: Gustavo Gili, 1981.

Hall, Budd L. MTU NI AFYA: Tanzania's Health Campaign. Washington, D.C.: Clearinghouse on Development Communication, $19 \mathrm{n}$.

Hanssen, Andrew, Steven Kozlow, and Anne Olsen. "RADECO: Radio-Based Primary Education in the Dominican Republic.” DCR 42 (June 1983).

Hein, Kurt J. “Community Participation in Radio for Development: Radio Bahá'í, Otavalo, Ecuador.” Unpublished Ph.D. thesis, Northwestern University, Evanston, Illinois, 1985.

"Community Radio Thriving in Ecuador: Otavalo Indians Running Their Own Show." DCR 40 (Dec. 1982).

_ _ . "Community Radio in Ecuador Meeting People's Needs." DCR 42 (June 1983). 
_ • "Community Radio in Ecuador Playing Local Music, Strengthening Cultural Ties.” DCR 44 (Dec. 1983 ). . Radio Bahá'í; Ecuador. London: George Ronald, 1988.

. "Participatory Radio for Rural Development: The Bahá'í Experiments." Unpublished paper delivered at the Second Colloquium on Communication and Culture, Bled, Yugoslavia, Sept. 1988.

Helwig, John E, and Jamesine Friend. “Teaching Where There are No Schools.” DCR 49 (Spring 1985).

Hewett, Anthony. “Communicating a Vision.” UNICEF News 84.2(1975).

Hochheimer, John L. “Community Radio in the United States: Whom Does it Serve?” RTV 3 (1988).

Howkins, John. “The Management of the Spectrum.” InterMedia 7.5 (Sept. 1979).

Hoxeng, James, Alberto Ochoa, and Valarie Ickis. Tabacundo: Dialogo Radiofonico. Nota Tecnica No. 10. Amherst: Center for International Education, University of Massachusetts, 1975.

Hudson, Heather E. “Modern Technologies Can Serve Traditional Cultures.” InterMedia 11.2 (March 1983).

Imhoof, Maurice. "Interactive Radio in the Classroom: Ten Years of Proven Success.” DCR 48 (Winter 1985).

Imhoof, Maurice, and Philip R. Christensen. Teaching English by Radio: Interactive Radio in Kenya. Washington, D.C.: Academy for Educational Development, 1986.

Interactive Radio Instruction Handbook. Washington, D.C.: Clearinghouse on Development Communication, 1988.

InterMedia staff. "The Chinese Way of Broadcasting.” InterMedia 5.2 (April 1977).

__ . "France: The Monopoly vs. Radio Libre." InterMedia 8.3 (May 1980).

Jakubowicz, Karol. "Mass and Communication Revisited." InterMedia 13.1 (Jan. 1985). . "Democratising Communication in Eastern Europe." InterMedia 15.3 (May 1987).

Jamison, Dean T., and Emile G. McAnany. Radio for Education and Development. Beverly Hills: Sage Publications, 1987.

Jimenez, Jorge Humberto. “Colombia Could Have the Biggest School in the World.” DCR 53 (Spring 1986).

Kidd, Dorothy. "Learning with Northern Lights.” Interadio 1.1(Spring 1988).

Kiely, Jeffery G., and Helen Keily. "Native American Bahá'í Institute.” Unpublished paper in Amoz Gibson Centre Library.

Kogawa, Tetsuo. “Japanese Block-Wide Radiocasts.” World Paper (March 1987).

. "Free Radio in Japan.” Cultures in Contention. Seattle: Real Comet Press, 1985.

. "New Trends in Japanese Popular Culture." Telos 64 (Summer 1985).

__ . "Japanese Mini-FM Station Raided." The Democratic Communique, Union for Democratic Communications, Dec. 19R5.

__ . "Recent Trends in Mini-FM." Photocopied letter, July 1988.

Kweekeh, Florida A. “Liberia’s New Health Vehicle: Radio.” DCR 56.1 (1987). "Radio for Rural Development in Liberia." InterMedia 15.2(Mar. 1987).

_ _ "The Role of Regional, Local and Community Radio in Rural Development in Liberia: A Case Study of the Liberian Rural Communications Network." RTV 3(1988).

LaChance, Jacques. "Native Radio: Speaker in the Woods.” Interadio 1.1(Spring 1988). 
Laflin, Michael. “A Study in Decentralization: The Liberian Rural Communications Network.” DCR 58.3(1987).

Lansman, Jeremy. "Workshop Report: Appropriate Technology for Low-Powered Radio.” Published notes, 1st AMARC World Conference of Community Oriented Radio Broadcasters, Vancouver, B.C., 1981.

Lasswell, Harold. Communication in a Divided World: Opportunities and Constraints. London: International Institute of Communications, 1977.

Lee, Dorothy. "The Cultural Curtain.” Guidelines for Peace Corps Cross Cultural Training. Washington, D.C.: U.S. Peace Corps, 1970.

Lights 0/ Guidance. Comp. Helen Hornby. Rev. ed. New Delhi: Bahá’í Publishing Trust, 1988.

Long, Mark. "Solar-Powered Radios in Central America Open New Lines of Communication." DCR 36 (Dec. 1981).

Low, Colin. "Media as Mirror." A Resource for the Active Community. Canadian Radio-Television Commission (CRTC), 1974.

LPB staff. Limited Area Broadcasting. 4th ed. Bacton, Pennsylvania: LPB Inc., 1979.

.”Electrical Connections of a Carrier Current System” Bacton, Pennsylvania: LPB Inc., April 1983.

_ . ."Campus Radio-FM or AM?" Bacton, Pennsylvania: LPB Inc., Oct. 1978.

_ . Data sheets on transmitters used by CBC Northern Service, Provided by Bacton, Pennsylvania: LPB Inc ..

__ ."LPB's Carrier Current Consulting and Complementary Review Services.” Bacton, Pennsylvania: LPB Inc., June 1979.

Lyman, Vianne, and Gail Martin. "Access by Community Groups." A Resource for the Active Community. CRTC, 1974.

McAnany, Emile G. Radio's Role in Development: Five Strategies of Use. Washington, D.C.: Clearinghouse on Development Communication, 1976.

McLuhan, Marshall. Understanding Media: The Extensions of Man. New York: Signet Books, 1964.

Maeda, Sharon. "Community Radio Survey-USA.” Published notes, 1st AMARC World Conference of Community Oriented Radio Broadcasters, Vancouver: 1981.

Mayo, John K., Charles B. Green, and Miguel E. Vargas. "Radio Santa Maria: A Case Study for Participatory Evaluation." DCR 48(Winter 1985).

Meadowcraft, Jean. "Radio Science: Completing the Interactive Radio Instruction Curriculum.” DCR 49(Spring 1985).

Milam, Lorenzo Wilson. The Radio Papers. San Diego: Mho \& Mho Works, 1985.

Miller, Jerry, and Albert Houston. “Solar Energy Powers Two-Way Radios.” DCR 28(Oct. 1979).

Mitchell, Linda. "A Survey of Activities." A Resource for the Active Community. Canadian Radio-Television Commission, 1974.

Mozambique, People's Republic of. Communication and Development. Ministry of Information, 1975.

Nascimento, Christopher A. The World Communication Environment: Conflict or a Free and Open Encounter. Guyana Ministry of Information, Georgetown, 1981.

Nkinyangi, John A. "Review and Assessment of Radio as a Medium Facilitating Community Participation." 
Methods and Media in Community Participation. Uppsala, Sweden, 1983.

de Noriega, Luis Antonio, and Frances Leach. Broadcasting in Mexico. London: Routledge and Kegan Paul, 1979. Oxford, Rebecca L. "Kenya's Radio Language Arts Project: Evaluation Results.” DCR 51(Autumn 1985).

Parija Herrera, Talia. "Community Radio for the Pueblos.” InterMedia 15.1 (Jan. 1987).

Pine, Richard. "Broadcasting: Public or Private? A Survival Strategy for Dinosaurs." InterMedia 15.4/5(July/Sept. 1987).

Ploman, Edward. "The Communications Revolution.” InterMedia 9.5(Sept. 1981). "Proposal: A Media Policy." InterMedia 7.5(Sept. 1979).

Postgate, Richmond, Peter M. Lewis, and William Southwood. "Appropriate Communications in the Third World." InterMedia 7.4(July 1979).

Rada, Stephen E. “Ramah Navajo Radio and Cultural Preservation.” Journal of Broadcasting 22.3(1978).

"Radio in the Trenches." Interadio 1.1 (Spring 1988).

“Radio Works as Sioux’s Cultural Hookup.” (Denver) Rocky Mountain News, May 9,1988.

Real, Michael R. Mass-Mediated Culture. Englewood Cliffs, New Jersey: Prentice-Hall, 1977.

“Resources List.” Interadio 1.1(Spring 1988).

Rib, Virginia Berges. "RADECO: A Precedent in Education.” DCR 60.1(1988).

Rishel, Brad A. "Media Use Development: A Proposal for the Native American Bahá'í Institute, Houck; Arizona." Unpublished paper prepared at Wichita State University, 1987.

Rodrigo, Miguel, and Xavier Ruiz-Collantes. "Chronologia." De las Ondas Rojas a las Radios Libres. Ed. LIuis Bassets. Barcelona: Gustavo Gili, 1981.

Rogers, Everett, and Lawrence Kincaid. "Communication is Networks and Convergence." InterMedia 10.1 (Jan. 1982).

Salter, Liora. Community Radio. CRTC, undated.

Searle, Barbara. "Evaluation of Three Interactive Radio Projects." DCR 49 (Spring 1985).

Sedlak, Philip A.S. “Teachers Interact with Radio in Nepal.” DCR 56.1 (1987).

Selected Project Profiles: Agricultural Communications, Health, Radio. 3 vols. Washington, D.C.: Clearinghouse on Development Communication, 1987.

Shoghi Effendi. Principles of Bahá'í Administration. Wilmette: Bahá'í Publishing Trust, 1968.

Shue, Vivienne. "China: On the Wire.” InterMedia 8.2 (Mar. 1980).

Soedjatmoko. The Future and the Learning Capacity of Nations: The Role of Communications. London: International Institute of Communication, 1978.

Sofia, Bruno. "Community Radio Survey-Italy and Europe." Published notes, 1st AMARC World Conference of Community Oriented Radio Broadcasters, Vancouver B.C., 1981. 
Spain, Peter L. “The Fourth R-(Interactive) Radio.” DCR 49 (Spring 1985).

Splichal, Slavko. "Radio as a Means of Communication." RTV 1988/3.

Stephens, K. Dean. “Alternative Energy for Radio Stations.” DCR 58 (Autumn 1987). "AM Radio: Regrouping for the 21st Century." Broadcast Engineering. May 1989. . "Village Radio: Opportunity Knocking?" Bahá'í News. March 1988.

_ . "New Radio Technologies and Models." RTV 1988/3.

__. "Micro-Power and 'Leaky Cable' Village Radio." Vanguardia 2.1 (Jan. 1989).

_ . "Power to the People: Not Just in Developing Countries" DCR 64 (Spring 1989).

Stuart, Martha. "Village Solutions Make Global Community.” InterMedia 9.5 (Sept. 1981).

Stuckens, Guy. "Radio Radio What is Radio?" Interadio 1.1 (Spring 1988).

Tehranian, Majid. "Modernisation, Communication and Community Development." Issues in Communications. No.2. London: International Institute of Communications, 1978. . “A Need for New Indicators.” InterMedia 8.1 (Jan. 1980).

Theroux, James M. Effective Educational Radio: An Approach to Analyzing Programs. Amherst: Center for International Education, University of Massachusetts, 1975.

United States National Paper. Science and Technology for Development. United Nations Conference on Science and Technology for Development, New York, 1979.

Universal House of Justice, Letter to the Bahá'í of the World, Oct. 20, 1983.

_ . "To the Peoples of the World" Bahá'í Studies 14 (1986).

University of Iowa. "Program for Development Support," Council on International and Comparative Studies, University of Iowa, Iowa City, undated.

Ward, Douglas. “Access Radio in the Northwest Territories.” Paper prepared for Biennial Conference, Commonwealth Broadcasting Association, Toronto, Jan. 1982.

WAWATAY Native Communications Society. "Community Development through Communications." Pamphlet, Sioux Lookout, Ontario, undated. 